Ewa Kubicka

Uniwersytet Gdański

\title{
Wyobrażenia społeczne dotyczące osób należących do subkultury skinheadów
}

Skinheadzi stanowią jedną z najstarszych współczesnych subkultur. Przez wiele lat dochodziło $\mathrm{w}$ niej do licznych zmian i rozłamów, a mimo to wizerunek skinheadów prezentowany przez współczesne środki masowego przekazu wciąż jest jednoznaczny: są to grupy młodych, krótko ostrzyżonych mężczyzn, ubranych w paramilitarne stroje, odpowiedzialnych za wybryki chuligańskie, bijatyki i napady. Media odczłowieczają skinheadów, przyrównując ich do maszyn nienawiści ${ }^{1}$. Stereotyp „złego skina” reprodukują również publikacje dotyczące subkultur młodzieżowych, które najczęściej koncentrują się na patologiach, agresji, przestępczości lub skrajnych poglądach politycznych skinheadów, czyli wyłącznie na negatywnych aspektach funkcjonowania w tej grupie ${ }^{2}$. Taki obraz tej subkultury jest zgodny z jej potocznym rozumieniem. Subkultura ta bowiem jest kojarzona z odrzucaniem pewnych wzorów kulturowych, buntem oraz zachowaniami godzącymi w podstawowe wartości społeczne. Nie jest to jednak jedyny jej obraz, tak jak nie jest to jedyne i właściwe jej rozumienie w naukach społecznych (Zdulski, Zdulski, Wrzesień 2011).

Trudno dokładnie określić, kiedy pojawili się skinheadzi. Ich początki powszechnie datuje się na okolice roku 1968, ale de facto pierwszych skinheadów widywano w kręgach modsów już w 1964 roku. Nazwa "skinhead” wywodzi się od charakterystycznie krótko ostrzyżonych włosów, przez które można zobaczyć skórę głowy (Marshall 1991).

W pierwszej połowie lat sześćdziesiątych XX wieku w londyńskiej dzielnicy Soho zaczęła rodzić się subkultura modsów, którzy zwracali szczególną uwagę na dobór stroju, wybierali klasyczne, eleganckie garnitury - liczyły się stonowane kolory oraz schludny wygląd. Podobnie jak Teddy boys fascynowali się amerykańską kulturą masową, zwłaszcza muzyką rockową i „czarną muzyką”. Modsi w przeciwieństwie do Teddy boys, nie brali jednak udziału w atakach na imigrantów z Karaibów (Zdulski, Zdulski, Wrzesień 2011). W 1964/1965 roku modsi

\footnotetext{
${ }^{1}$ Taki wizerunek skinheada można spotkać w filmach Fanatyk (The Beliver, rok 2001, reż. Henry Bean), Romper Stomper (rok 1992, reż. Geoffrey Wright), Rosja 88 (Rossiya, rok 2009, reż. Pavel Bardin), Skinheadzi (Teste rasate, rok 1993, reż. Claudio Fragasso), Teraz Polska (rok 2005, reż. Michał Biliński).

2 Przykładem może być tu powieść dla młodzieży autorstwa Heidi Hassenmüller Czarne, czerwone, śmierć.
} 
wydawali się być łagodną odmianą młodzieżowej subkultury. Podejrzewano, że ukrytym wzorcem osobowym dla nich jest paniczyk z klasy średniej. Frustracja $z$ powodu niezaspokojonych aspiracji materialnych przeradzała się jednak $w$ agresję, znajdującą wyraz w bójkach $\mathrm{z}$ antagonistycznymi grupami młodzieżowymi. Około 1966 roku w wyniku starć modsów z wywodzącymi się z "nizin” społecznych rockersami, z modsów wyłonił się bardziej agresywny odłam - hard modsi, których uważa się za bezpośrednich protoplastów subkultury skinheadów. Zbierali się w klubach, gdzie grano murzyńską muzykę soul, a później importowane z Jamajki ska, blubeat i rock-steady (Wilk 1994). Jamajska muzyka rozwijała się w Wielkiej Brytanii dzięki osiadłym tam imigrantom z Karaibów. Młodzi modsi $\mathrm{i}$ hard modsi wchodzili $\mathrm{w}$ relacje z czarnoskórą młodzieżą - rude boys i starali się we wszystkim naśladować swoich czarnych rówieśników (Marshall 1991). Prosty, szybko udzielający się rytm muzyki reggae sprawił, że stała się ona bardzo popularna wśród skinheadów (Marshall 1991).

Niemal równoległym procesem było naśladownictwo stylu białych skinheadów przez czarnych imigrantów. $Z$ wymieszania tych stylów ukształtował się pierwotny wizerunek zewnętrzny skinheada (Janicki, Pęczak 1994).

Pierwsi skinheadzi oprócz wspólnych zainteresowań muzycznych solidaryzowali się $\mathrm{z}$ karaibską młodzieżą także $\mathrm{w}$ wykorzystywaniu politycznych zamieszek do ślepego wandalizmu i walk z policją. Potwierdza to istnienie gangów tworzonych na podstawie solidarności dzielnicowej. Ich członkami byli zarówno biali młodzieńcy, jak i młodzi imigranci (Wilk 1994).

Oprócz muzyki bardzo istotnym czynnikiem, który przyczynił się do rozwoju subkultury skinheadów, był football. Zdobycie przez Anglię w 1966 roku mistrzostwa świata spowodowało wzrost zainteresowania piłką nożną, również wśród skinheadów. Prasa zyskiwała popularność, opisując w sensacyjny sposób walki stadionowe skinheadów, a potępiające artykuły tylko przydawały temu reklamy i rozpowszechniały footballowy chuliganizm (Marshall 1991). Autorzy nie są zgodni co do roli skinheadów $\mathrm{w}$ rozpętaniu fali przemocy na stadionach i poza nimi. Natomiast faktem jest, że niektóre elementy skinheadowskiej garderoby, takie jak ciężkie buty (od których angielscy kibice nazywani byli później „,boot boysami"), stały się inspiracją dla członków klubów piłkarskich. W efekcie wielu spośród kibiców wyglądało jak typowi skinheadzi, chociaż nie do końca identyfikowali się z nimi. Stanowili oni raczej chuligańską, stadionową subkulturę, której celem były „zadymy” z fanami innych klubów i policją (Zdulski, Zdulski, Wrzesień 2011).

Ówcześni skinheadzi walczyli też z potomkami rockersów oraz z hipisami. Największe zainteresowanie mediów wzbudzała jednak skinowska przemoc skierowana przeciwko Azjatom żyjącym w Wielkiej Brytanii. Paki-bashing (tłuczenie Pakistańczyków) stało się kwestią tak głośną, że uznano ją za jedną z ważniejszych w rozmowach pomiędzy brytyjskim a pakistańskim rządem. Nie były to jednak zwykłe rasistowskie ataki, jak przedstawiały to media. Wśród skinheadów - oprócz rdzennie brytyjskiej młodzieży - byli przecież również młodzi Grecy, Karaibowie i inni imigranci o rozmaitych kolorach skóry. Duży napływ ludności ze środkowej Azji czy Ugandy powodował u rodowitych Brytyjczyków panikę związaną z rynkiem pracy. Azjatów postrzegano jako konkurentów, którzy mogą zabrać pracę i domy. W przemyśle ciężkim następowały masowe 
zwolnienia, a tradycyjne robotnicze społeczności były zagrożone ze strony planistów miejskich, którzy zamierzali zrezygnować $\mathrm{z}$ budowy tanich, wielopiętrowych bloków. Kolor skóry imigrantów powodował, że szybko zaczęto obwiniać ich za problemy dotykające Wielką Brytanię. Karaibów na tamten czas wchłonął już brytyjski styl życia. Gangi czarnych skinów często zwanych afro boys mogły ścierać się z gangami białych czy nawet gangami wielorasowymi, ale było to rezultatem walki o terytoria, nie rasizmu. Tworzenie dzielnic zamieszkiwanych wyłącznie przez imigrantów potęgowało wrażenie zamieszek na tle rasowym (Marshall 1991).

Z powodu medialnej nagonki na skinheadów, problemów z policją, trudności ze znalezieniem pracy wynikających z niechęci społeczeństwa oraz psucia wizerunku subkultury przez najbardziej agresywnych jej członków subkultura skinheadów około roku 1974 zaczęła obumierać (Bąk 2005).

W 1976 roku podczas rozkwitu subkultury punk skinheadzi pojawili się ponownie. Rozpoczął się wtedy drugi etap $\mathrm{w}$ ich historii, który przyniósł im popularność na całym świecie (Bąk 2005). Skinheadzi w pierwszej fali subkultury punk dopatrywali się czegoś na wzór hipisów - młodych ludzi tworzących nową, sztuczną, bezsensowną modę, która szybko minie. Sam punk rock mimo wszystko spodobał się skinheadom, a z czasem antyhipisowska postawa punków zjednała te dwie subkultury ze sobą (Bąk 2005). Dokonał się wtedy również rozłam skinheadów na młodsze pokolenie popierające punków i starszych przedstawicieli, którzy stanowili przyboczną gwardię konserwatywnych w swoich poglądach Teddy boysów. Ze skinheadów popierających Teddy boysów najpewniej wyłoniły się rasistowskie odłamy tej subkultury.

Garry Bushell z muzycznego tygodnika "Sounds" dokonał na krótki czas integracji skinheadów lansując okrzyk "Oi!" jako hasło pojednawcze, wspólne dla skinheadów i punków. Mimo tego wkrótce znów dokonał się podział o podłożu politycznym, punki odstąpiły street punk i okrzyk „Oi!" skinheadom i zwróciły się w stronę nowego gatunku muzycznego: hard core'u (Bąk 2005). Mocno zaangażowane społecznie i politycznie teksty piosenek oiowych z czasem zaczęły przyciągać uwagę różnych partii i ugrupowań, które wśród sfrustrowanej młodzieży poszukiwały poparcia. Doprowadziło to do politycznej inwigilacji skinheadów zarówno ze strony ugrupowań prawicowych, jak i lewicowych, jednak $w$ tamtym czasie nie wykazywali jeszcze zainteresowania polityką (Bąk 2005).

Gdy do Anglii napłynęła kolejna fala imigrantów, przyczyniając się do wzrostu bezrobocia wśród rdzennych Anglików, skinheadzi wywodzący się głównie ze środowisk robotniczych zareagowali niechęcią do napływowej ludności. Niektórzy z nich zaczęli głosić wręcz rasistowskie hasła, a także interesować się takimi partiami jak British National Party (Brytyjska Partia Narodowa) czy też National Front (Front Narodowy), którym przyświecała idea narodowego socjalizmu (Bąk 2005).

Wzrost liczby skrajnie prawicowych skinheadów i neonazistowskich organizacji pociągnął za sobą równie obfity rozwój odłamów lewicujących i apolitycznych oraz antyfaszystowskich i antyrasistowskich takich jak SHARP (Skinheadzi Przeciwko Rasistowskim Uprzedzeniom) walczących nie tylko z rasizmem, ale i z postrzeganiem skinheadów jako nazistów (Filipiak 1999). 
Nazi skini stanowili wtedy jeszcze wewnętrznie spójną grupę, a ze względu na brutalne ataki na przedstawicieli innych nacji także bardzo kontrowersyjną, przez co skupiali na sobie całą uwagę środków masowego przekazu. Doprowadzili tym samym do wypaczenia wizerunku skinheada i wykreowania w świadomości społecznej powszechnego do dzisiaj wizerunku skinheada jako nazisty (Bąk 2005).

Znajomość historii subkultury jest dla jej członków bardzo ważną kwestią, gdyż między innymi na jej podstawie kształtuje się subkulturowa tożsamość. Dawniej wiedzę taką młodzież czerpała przede wszystkim od starszych znajomych, dziś dzięki łatwemu dostępowi do informacji głównymi źródłami wiedzy są internet, telewizja ogólnodostępna, literatura i filmy, w których bohaterowie należą do subkultur.

Celem przeprowadzonych badań było określenie, jakie są współczesne wyobrażenia społeczne dotyczące subkultury skinheadów, oraz jak kształtują się one w zależności od źródeł, z których ludzie czerpią wiedzę na temat tej subkultury.

W związku z celem badań sformułowano następujące pytania: z jakich źródeł ludzie czerpią wiedzę na temat subkultury skinheadów? Co wiedzą na temat subkultury skinheadów? Jak społeczeństwo odbiera osoby należące do subkultury skinheadów?

Wykorzystano kwestionariusz wywiadu z kafeterią otwartą i koniunktywną oraz z pytaniami otwartymi (Pilch, Bauman 2001). Formularz skonstruowano tak, by respondenci mieli jak największą swobodę wypowiedzi oraz aby niczego osobom badanym nie sugerować. Badania prowadzono przez internet, by dotrzeć do jak największej liczby respondentów. Kwestionariusze wypełniane były anonimowo. Respondenci znali cel prowadzonych badań. Wyniki poddano procesowi kodyfikacji (Pilch, Bauman 2001).

Kwestionariusz wypełniło 160 osób, w tym 94 kobiety oraz 66 mężczyzn. Wiek większości badanych mieścił się w przedziale 18-25 lat (55\%). Strukturę wieku osób badanych przedstawia wykres 1 .

W pytaniu o źródła wiedzy na temat subkultury skinheadów zastosowano koniunktywną kafeterię, aby badani mogli zaznaczyć więcej niż jedno źródło swojej wiedzy. Badanie wykazało, że najczęściej deklarowanymi źródłem wiedzy o skinheadach są: przedstawiciele tej subkultury, opowieści znajomych

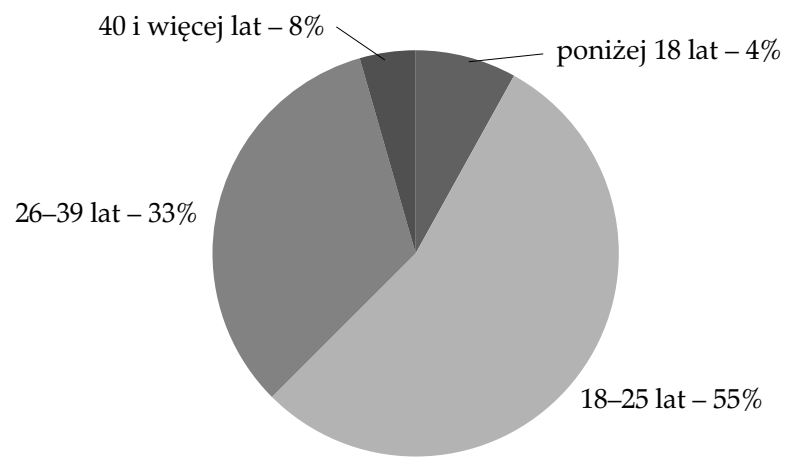

Wykres 1. Wiek respondentów

Źródło: opracowanie własne. 
i internet. Najmniej popularnym źródłem wiedzy są zaś zajęcia edukacyjne. Wykres 2 przedstawia deklarowane źródła wiedzy na temat subkultury skinheadów.

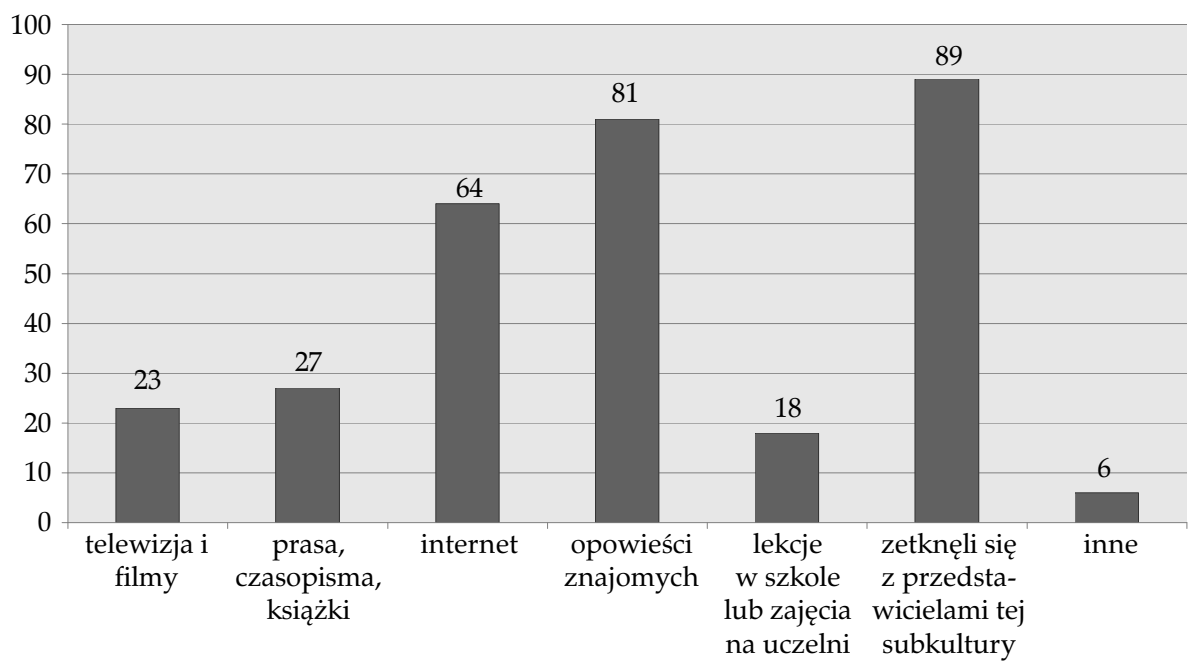

Wykres 2. Źródła wiedzy na temat subkultury skinheadów Źródło: opracowanie własne.

Osoby czerpiące wiedzę na temat skinheadów z filmów i telewizji najczęściej jako przykłady podawały następujące filmy: Więzień nienawiści (American History X, rok 1998, reż. Tony Kaye), Romper Stomper (rok 1992, reż. Geoffrey Wright), Fanatyk (The Beliver, rok 2001, reż. Henry Bean), To właśnie Anglia (This is England, rok 2006, reż. Shane Meadows), Made in Britain (rok 1982, reż. Alan Clarke), Być skinheadem (Skinhead Attitude, rok 2003, reż. Daniel Schweizer), Mechaniczna pomarańcza (A Clockwork Orange, rok 1971, reż. Stanley Kubrick). W kategorii literatury znalazły się natomiast Spirit of '69: A Skinhead Bible autorstwa George'a Marshalla oraz Krucjata łysogłowych Ewy Wilk (1994). W kategorii „inne” badani deklarowali, że ich źródłami wiedzy są teksty utworów muzycznych, osoby należące do tej subkultury, beletrystyka, bądź że nie czerpią wiedzy o tej subkulturze z żadnych źródeł.

Aby zbadać wyobrażenia społeczne respondentów dotyczące skinheadów, zadano im między innymi następujące pytania: czy osoba innego koloru skóry może należeć do tej subkultury? Czy do tej subkultury mogą należeć/należą kobiety? Kim są według Ciebie skinheadzi? Jaki jest Twój stosunek do osób należących do subkultury skinheadów?

Według zebranego materiału 46\% respondentów uważa, że do subkultury skinheadów nie mogą należeć osoby innego koloru skóry, $22 \%$ nie wie, jak odpowiedzieć na to pytanie, a tylko $32 \%$ zgodnie z prawdą uważa, że osoby o innym kolorze skóry mogą należeć do tej subkultury. Wyniki te świadczą o małej znajomości historii skinheadów u respondentów i potwierdzają stereotyp skinheada nazisty - głoszącego hasła białej siły. Znacznie lepiej przedstawia się wiedza respondentów na temat możliwości przynależności kobiet do tej subkultury. $77 \%$ badanych osób uznaje, że kobiety mogą należeć do subkultury skinheadów, $17 \%$ respondentów nie wie, czy kobiety mogą należeć do tej subkultury, a tylko $6 \%$ uważa, że kobiety nie mogą być jej członkami. Wyniki tych badań przedstawia wykres 3 . 


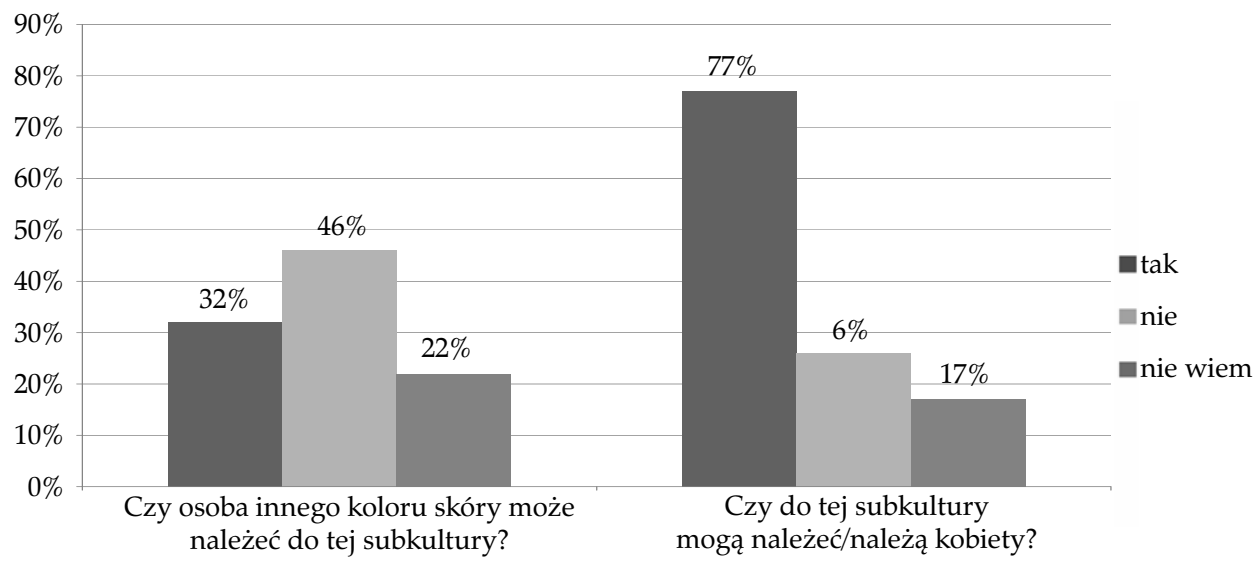

Wykres 3. Możliwość przynależności do subkultury skinheadów

Źródło: opracowanie własne.

Badania wykazały również, że stosunek respondentów do subkultury skinheadów jest w znacznej mierze obojętny (44\%), więcej respondentów ma stosunek do tej subkultury negatywny (22\%) niż pozytywny $(16 \%)$. Wśród odpowiedzi „inne” znalazły się między innymi takie wypowiedzi jak: „Mam do nich negatywny stosunek, boję się ich, ale mnie ciekawią", "Są mi obojętni dopóki ich idee, zachowania nie przybierają fanatycznego charakteru”, „To zależy od danej osoby".

Wykres 4 przedstawia stosunek respondentów do osób należących do subkultury skinheadów.

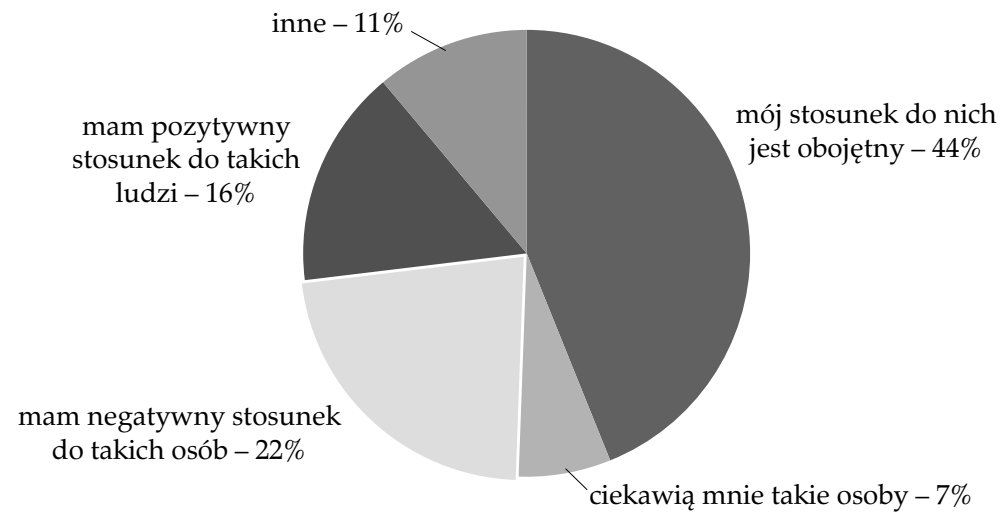

Wykres 4. Stosunek do osób należących do subkultury skinheadów

Źródło: opracowanie własne

Na podstawie odpowiedzi na pytanie o źródła wiedzy o subkulturze skinheadów badani zostali podzieleni na dwie grupy:

1. Respondenci, którzy jako źródła swojej wiedzy o subkulturze skinheadów deklarowali telewizję, filmy, prasę książki, zajęcia edukacyjne, internet oraz opowieści znajomych; 
2. Respondenci, którzy wśród deklarowanych przez siebie źródeł wiedzy wskazywali własne doświadczenia oraz na okazjonalną styczność z przedstawicielami tej subkultury.

Podział ten przedstawia wykres 5.

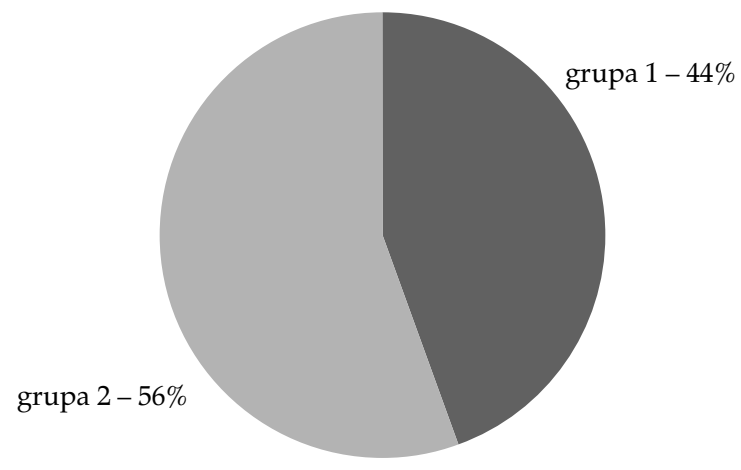

Wykres 5. Styczność osób badanych z członkami subkultury skinheadów Źródło: opracowanie własne.

Badania wykazały znaczne różnice w stosunku osób badanych do skinheadów w zależności od tego, do której z tych grup należeli badani. W obu tych grupach przeważała obojętność wobec skinheadów, największa różnica pojawiła się między tymi grupami w przypadku pozytywnego podejścia. Wśród osób należących do pierwszej grupy tylko $2 \%$ zadeklarowało pozytywny stosunek do skinheadów, natomiast w grupie drugiej pozytywne nastawienie zadeklarowało $28 \%$ badanych. Tendencja ta dotyczy również negatywnego stosunku do skinheadów. Badani, którzy mieli styczność z przedstawicielami tej subkultury, rzadziej deklarowali negatywne odczucia (17\%), niż ci, którzy wiedzę czerpią głównie ze źródeł takich jak telewizja, Internet czy też opowieści znajomych. Swiadczy to o tym, że kreują one negatywne wyobrażenia dotyczące skinheadów.

Stosunek respondentów do subkultury skinheadów w zależności od tego, do której z grup należą, przedstawia wykres 6.

Z odpowiedzi na pytanie „Kim są według Ciebie skinheadzi?” metodą kodowania wyłoniono następujące kategorie:

- nie wiem, kim są skinheadzi;

- skinhead to buntownik;

- skinhead to ekstremista (osoba nietolerancyjna względem wszystkiego, co inne, nacjonalista, rasista, nazista ksenofob, antysemita);

- skinhead to osoba agresywna;

- skinhead to mężczyzna;

- skinhead to osoba o niskiej inteligencji;

- skinheadzi to (normalni) ludzie;

- skinheadzi to ludzie o specyficznych poglądach (w tej kategorii znalazły się wypowiedzi określające skinheadów jako osoby o charakterystycznym światopoglądzie, ceniące sobie konkretne wartości bez wskazania, jakie to wartości i ich oceny); 


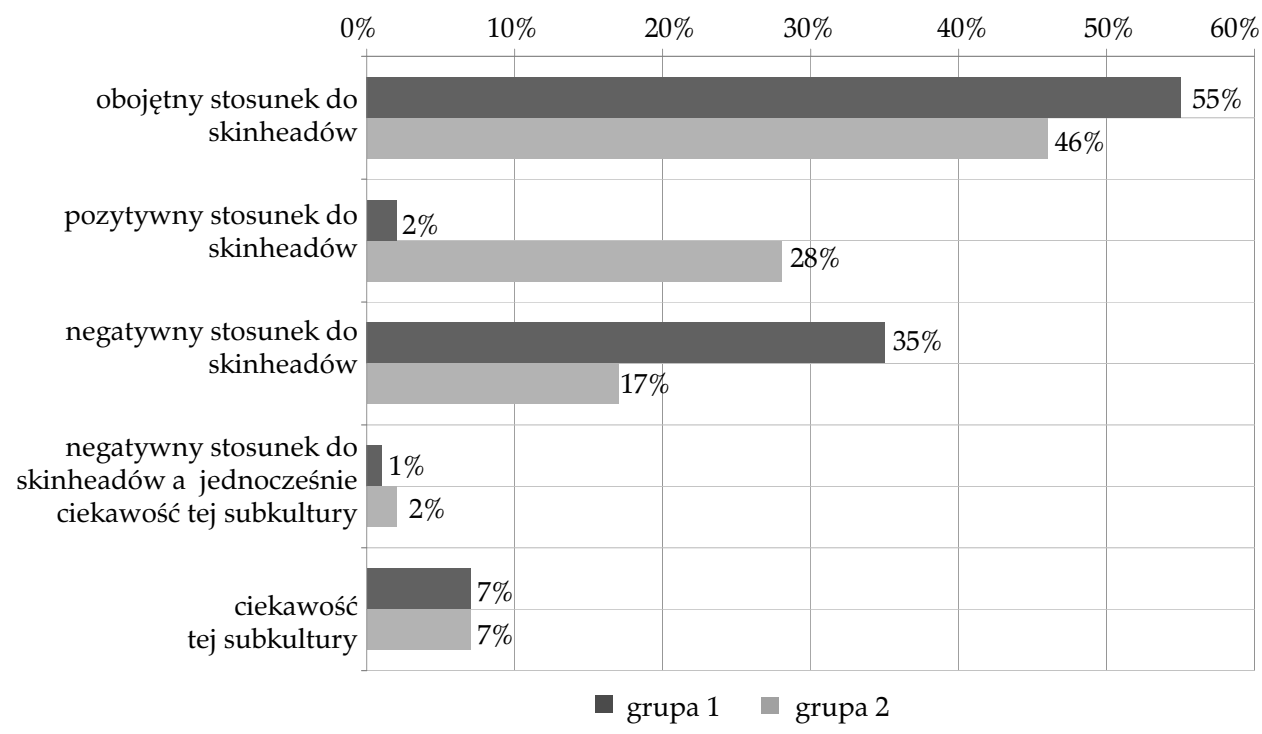

Wykres 6. Stosunek do subkultury skinheadów - analiza z podziałem na grupy Źródło: opracowanie własne.

- skinheadzi to subkultura wyróżniająca się charakterystycznym wyglądem i zainteresowaniami;

- skinheadzi to margines społeczny;

- skinheadzi to kibole, chuligani, blokersi;

- skinheadzi to dobrzy ludzie;

- skinheadzi to lojalni kumple;

- skinheadzi to źli ludzie;

- skinheadzi różnicowana grupa obarczona negatywnymi stereotypami;

- skinheadzi to ludzie z problemami;

- skinheadzi o zamknięte grono;

- skinheadzi to ludzie zmanipulowani.

Analiza występowania tych kategorii w zależności od źródeł, z których badani czerpią wiedzę na temat subkultury skinheadów, wykazała, że badani z grupy pierwszej częściej wypowiadali się o skinheadach w takich kategoriach jak: „nie wiem, kim są skinheadzi”, "skinhead to młody buntownik”, "skinhead to osoba agresywna", ,skinheadzi to margines społeczny", „skinheadzi to ludzie z problemami", "skinheadzi to zamknięte grono". Najczęściej respondenci z tej grupy określali skinheadów jako osoby o nazistowskich i ekstremistycznych poglądach oraz jako osoby agresywne. Respondenci, którzy swoje wyobrażenia dotyczące skinheadów ukształtowali między innymi na podstawie styczności z członkami tej subkultury, najczęściej określali skinheadów w kategoriach: „skinheadzi to subkultura wyróżniająca się charakterystycznym wyglądem i zainteresowaniami", „skinhead to ekstremista”, „skinheadzi to ludzie o specyficznych poglądach". Warto też zwrócić uwagę, że respondenci z tej grupy w opisie skinheadów posługiwali się szerszym wachlarzem kategorii. Wyniki przeprowadzonej analizy przedstawia wykres 7 . 


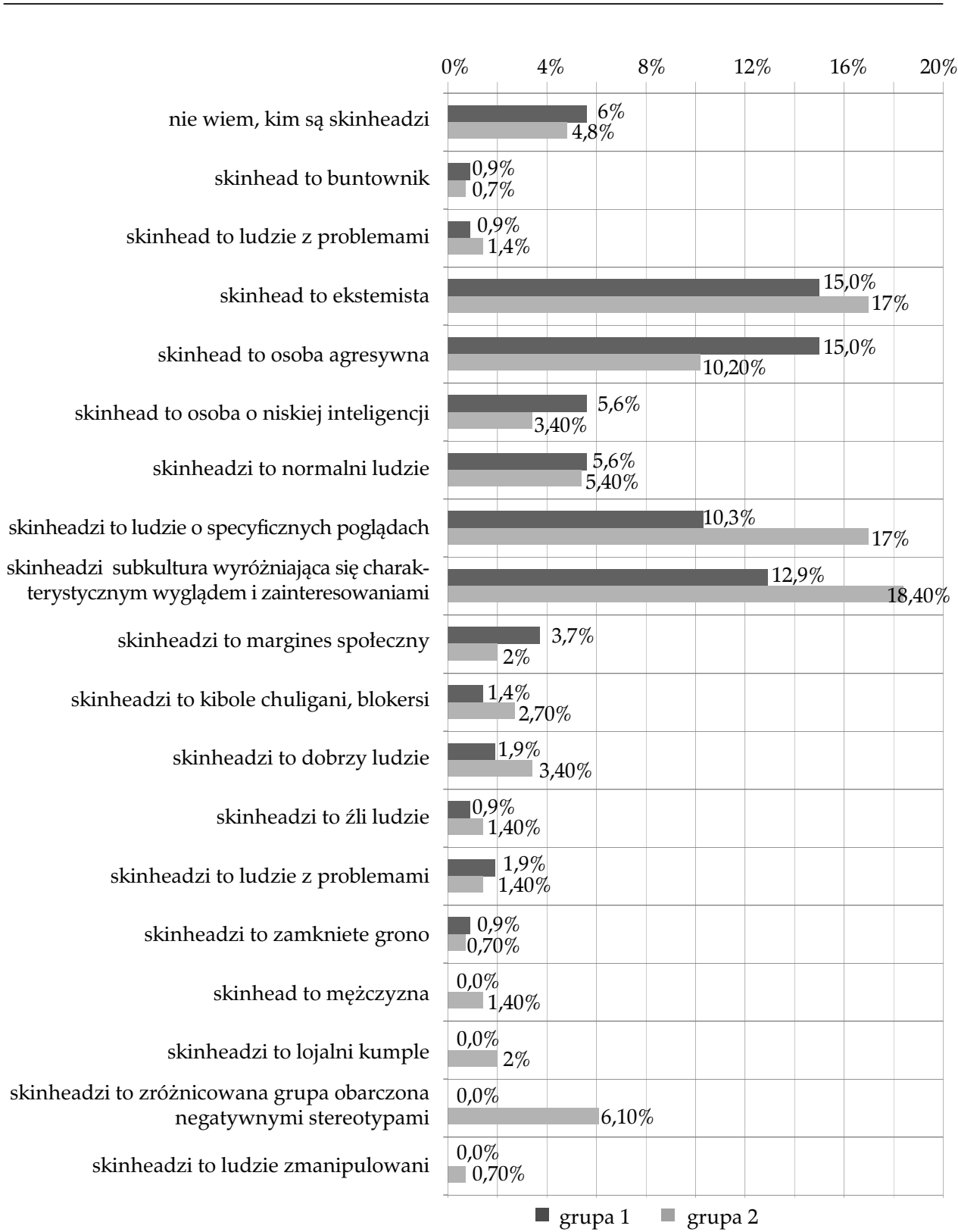

Wykres 7. Wyobrażenia dotyczące skinheadów - analiza z podziałem na grupy Źródło: opracowanie własne.

Przedstawione tu wyniki badań pokazały różnorodność wyobrażeń społecznych dotyczących subkultury skinheadów. Nadal jednak dominuje stereotyp skinheada jako agresywnego ekstremisty. Analiza wykazała również braki w wiedzy dotyczącej omawianej subkultury. Zaprezentowany materiał stanowi tylko część przeprowadzonych badań i ma zwrócić uwagę przede wszystkim na źródła wyobrażeń społecznych oraz na to, jak wpływają one na ich myślenie i stosunek do innych - de facto nie znanych im - ludzi. 


\section{Literatura:}

Bąk T.W., 2005, Skinheadzi w Polsce, Warszawa-Sandomierz: Wydawnictwo Diecezjalne i Drukarnia w Sandomierzu.

Filipiak M., 1999, Od subkultury do kultury alternatywnej. Wprowadzenie do subkultur młodzieżowych, Lublin: Wydawnictwo Uniwersytetu Marii Curie-Skłodowskiej.

Janicki M., Pęczak M., 1994, Polska siła. Skini, narodowcy, chuligani, Warszawa: Polska Oficyna Wydawnicza „BGW” we współpracy z P.P.H. REPLEY.

Jędrzejewski M., 1999, Młodzież a subkultury. Problematyka edukacyjna, Warszawa: Wydawnictwo Żak.

Lesiakowski K., Perzyna P., Toborek T., 2004, Jarocin w obiektywie bezpieki, Warszawa: Instytut Pamięci Narodowej. Komisja Ścigania Zbrodni przeciwko Narodowi Polskiemu.

Marshall G., 1991, Spirit of '69: A Skinhead Bible, Dunoon, wersja internetowa: http://spiritof-69.prv.pl/ [dostęp: 10.08.2015].

Pilch T., Bauman T., 2001, Zasady badań pedagogicznych. Strategie ilościowe i jakościowe, Warszawa: Wydawnictwo Żak.

Wilk E., 1994, Krucjata łysogłowych, Warszawa: Niezależna Oficyna Wydawnicza Nowa.

Zdulski M., Zdulski T., Wrzesień I., 2011, Ciernie miasta. Skinheadzi a ultraprawica w krajach Europy Środkowej, Jelenia Góra: Karkonoska Państwowa Szkoła Wyższa.

\section{Abstrakt}

Celem przedstawionych $\mathrm{w}$ artykule badań było określenie, jakie są współczesne wyobrażenia społeczne dotyczące subkultury skinheadów oraz jak kształtują się one w zależności od źródeł, z których ludzie czerpią wiedzę na temat tej subkultury. Analiza wyników badań pokazuje, że wyobrażenia społeczne i stosunek do subkultury skinheadów różnią się w zależności od źródeł z których respondenci czerpali wiedzę. Badania pokazały silny wpływ środków masowego przekazu na kształtowanie się negatywnego stosunku do tej subkultury.

\section{Słowa kluczowe}

skinheadzi, subkultury, oczekiwania społeczne, media

\section{Summary \\ Social Vision of Skinhead Subculture Members}

Aim of the research presented in the text is to show contemporary vision of skinhead subculture members and how the vision is shaped according to the source of knowledge on this particular social group. Analysis of the response show that the vision and approach to skinheads depends on the source of information on the group. Media - according to the research - has a great impact on the vision of this subculture.

Keywords

skinheads, subcultures, social expectations, media 


\section{RECENZJE/SPRAWOZDANIA}


